\title{
BENEFITS OF ENERGY STORAGE SYSTEMS FOR SMALL-SCALE WIND FARM DEVELOPMENT IN LATVIA
}

\author{
E. Groza ${ }^{1 *}$, M. Balodis², K. Gulbis' ${ }^{1}$ J. Dirba ${ }^{1}$ \\ ${ }^{1}$ Institute of Power Engineering, Riga Technical University, \\ 12/1 Azenes Str., Riga, LV-1048, LATVIA \\ ${ }^{2}$ Research and Development Department, Latvenergo, \\ 12 Pulkveza Brieza Str., Riga, LV-1230, LATVIA \\ *e-mail: Edgars.Groza@gmail.com
}

The paper covers the main aspects and restrictions on siting small-scale wind farms in Latvia and benefits of using energy storage systems with small-scale wind farms. The restrictions of siting have been analysed. Grid connection restrictions are addressed as the main issues for small-scale wind farm development in Latvia. Two small-scale wind farm models with similar properties have been made and analysed within the framework of the research. The paper proposes the idea for maximising the production of small-scale wind farm in a small area site with high wind potential.

Keywords: Energy storage, wind energy, wind farm.

\section{INTRODUCTION}

Nowadays renewable energy sources are more often penetrated in modern energy systems, especially wind and solar. There is a recent trend on wide deployment of distributed generation. As wind and solar power sources in their nature are stochastic, an issue on achieving a well-balanced power grid is raised. For modern power systems, the fluctuating power output can be a problem.
The placement and development of large wind farms in Latvia are strongly regulated and influenced by the government. As the modern power system is market based, wind power plants cannot rely on the government financial support. The developers must find an economically viable way for renewable development.

It is important to find a cost-effective balance to exploit small areas with high 
wind potential, while maximizing possible output of wind power plant and reducing capital investment [1]. For energy storage systems (ESS), it can be a solution to maximise benefits of small wind power plants [2].

\section{METHODS}

The aim of this article is to propose an optimal solution to exploit small territories for wind turbines, simultaneously maximising output and optimising connection possibilities.

The main hindrance to wind farm deve- lopment in Latvia is siting. Several siting restrictions have to be taken into account. The restrictions can be divided into four groups: environmental issues, grid connection issues, economic feasibility and social acceptance (Fig. 1).

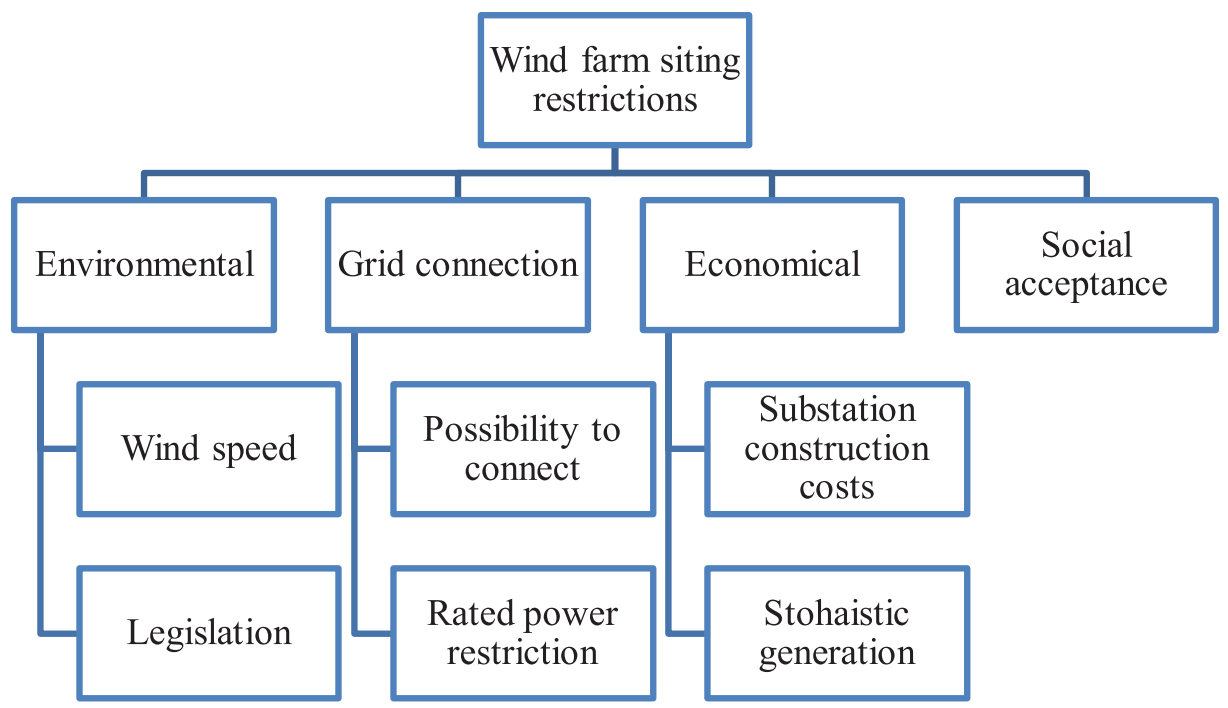

Fig. 1. Main restrictions for wind farm siting in Latvia.

Wind farm - a group of five or more wind turbines connected in a single system in which individual wind turbines are located no more than $2 \mathrm{~km}$ apart.

Small-scale wind farm is a group of less than five wind turbines connected in a single system in which individual wind turbines are located no more than $2 \mathrm{~km}$ apart.
In this paper, the economic feasibility as a siting issue is not considered, as well as social factors. Social acceptance of wind energy is an issue all over the world. The catalogue of potential solutions to overcome acceptance barriers for each country has been developed at the end of 2019 [3].

\subsection{Environmental Issues}

To place wind farms or few wind turbines, there are a lot of different restrictions to follow. There is a strict legislation (Cabinet Regulation No. 240 "General Rules for 
Spatial Planning, Use and Construction" of 30 April 2013) that determines where a developer is not allowed to set up a large number of wind turbines in Latvia. Wind turbines are positioned no closer than three rotor diameters apart. Some restrictions for wind farms according to the Latvian legislation are as follows:

- buffer zones for wind farms around cities or villages $-2 \mathrm{~km}$;

- wind farms shall be located no closer than five times the maximum height of wind turbine around residential houses in rural areas;
- wind farms shall be located no closer than $2 \mathrm{~km}$ from NATURA 2000 territories and micro-reserves designated for the protection of bird species, but from other NATURA 2000 territories - not closer than $500 \mathrm{~m} \mathrm{[4].}$

Due to these restrictions, there are many problems for siting wind farms. Limitations are less strict for wind power stations that are restricted to 4 wind turbines. For example, a buffer zone around cities or villages is reduced to $1 \mathrm{~km}$. In Fig. 2 all the limitations, as well as state forest lands, are placed on the map of Latvia, Kurzeme region.

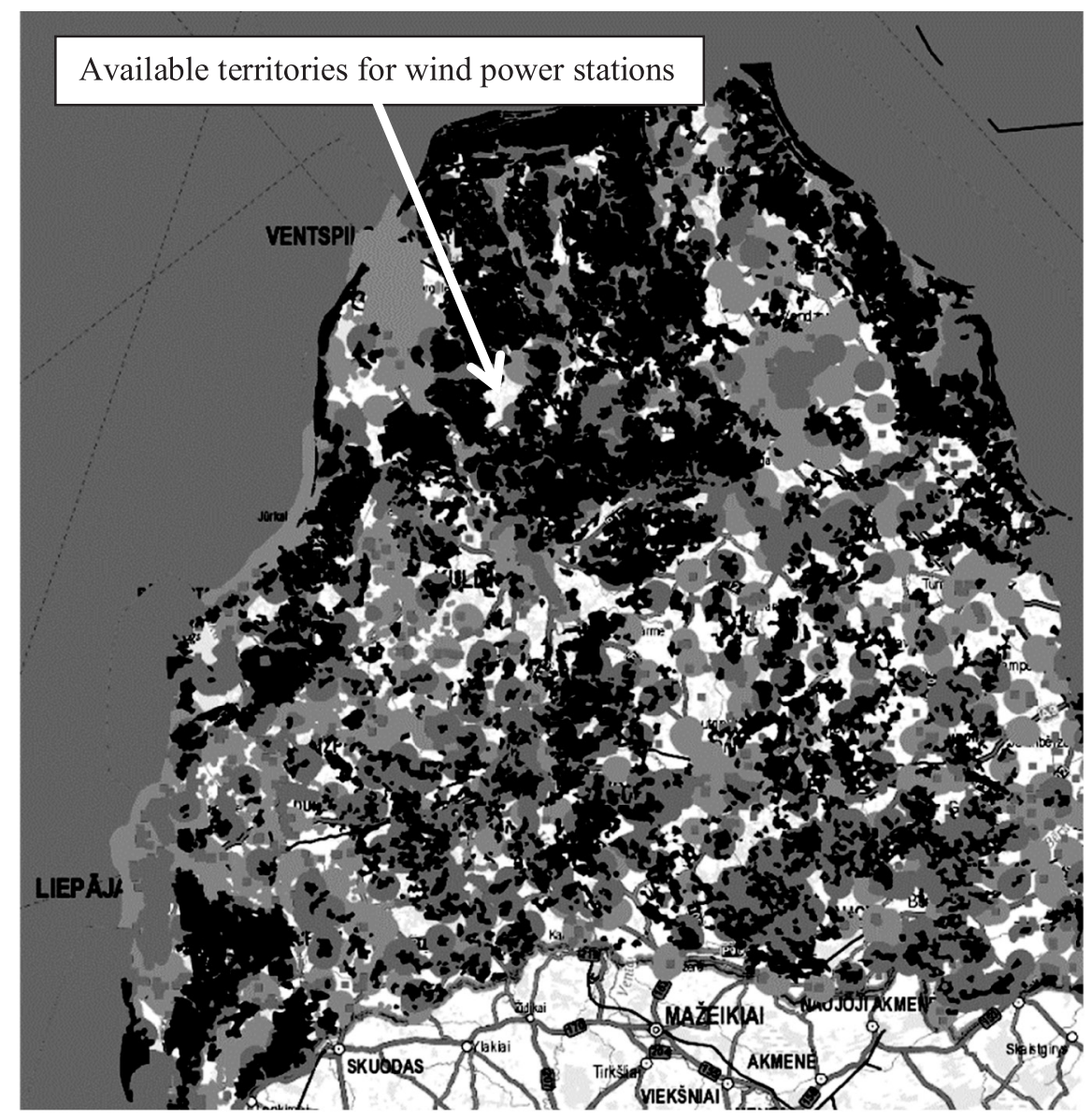

Fig. 2. Latvia, Kurzeme, different restrictions on the map.

There are some large territories where large wind farms can be built, but what cannot be seen on the map in Fig. 2 is that avail- able territories are small. There are always some environmental risks to take into account when planning wind power plants, 
for example, breeding sites of endangered bird species, feeding sites for bats. Environmental issues narrow down available areas even more. Ignoring all the different layout issues like wake losses, etc. optional area required for four turbines with a rotor diameter of $82 \mathrm{~m}$ is around 200 acres (around 81 ha) [5]. According to the Latvian regulation, the minimum territory should be around 48 ha. Thus, it is extremely complicated to develop wind farms and it is essential to maximise the use of the available territory.

It is important to mention that during

\subsection{Mean Wind Speed}

Latvian Environment, Geology and Meteorology Centre constantly collects wind measurement data at $10 \mathrm{~m}$ height. By using Hellmann exponential law (see Eq. (1)) that correlates the wind speed readings at two different heights, measurements at $10 \mathrm{~m}$ height are extrapolated to $100 \mathrm{~m}$ [6]. In the present research, Kurzeme has been chosen because the wind speed is much higher there than in other parts of the country, especially near the coastline. the writing and publishing of the article, Cabinet Regulation No. 240 "General Rules for Spatial Planning, Use and Construction" has changed. Some of the restrictions have been strengthened and some have been relaxed. For example wind turbines with rated power more than $2 \mathrm{MW}$ must be installed no closer than $800 \mathrm{~m}$ from residential or public buildings. The restriction applied to Natura 2000 has been erased, although each individual case is considered separately. The decisive factor is the environmental impact assessment.

$\frac{v}{v_{0}}=\left(\frac{H}{H_{0}}\right)^{\alpha}$,

where $v$ is the speed to the height $H, v_{0}$ is the speed to the height $H_{0}$ (frequently referred to as a 10 -meter height) and $\alpha$ is the friction coefficient or Hellman exponent.

In the research, it is important to obtain real wind measurement data. A high-quality wind speed data are crucial to project the power generation estimates and simulate the real case scenario [7].

\subsection{Grid Connection Issues and Economic Feasibility}

Distribution system operator (DSO) in Latvia forbids connecting a generation that is larger than $10 \mathrm{MW}$ to its grid [8]. Therefore, all power stations that have large generation power must be connected to the grid of a transmission system operator (TSO). However, this connection cannot be completed with simple substation with only one transformer as illustrated in Fig. 3a. The connection to the TSO grid is possible only by completing a more complicated circuit illustrated in Fig. 3b, which is also more expensive. Building expensive substations to connect to the TSO for a small wind or solar farm may not be economically viable.

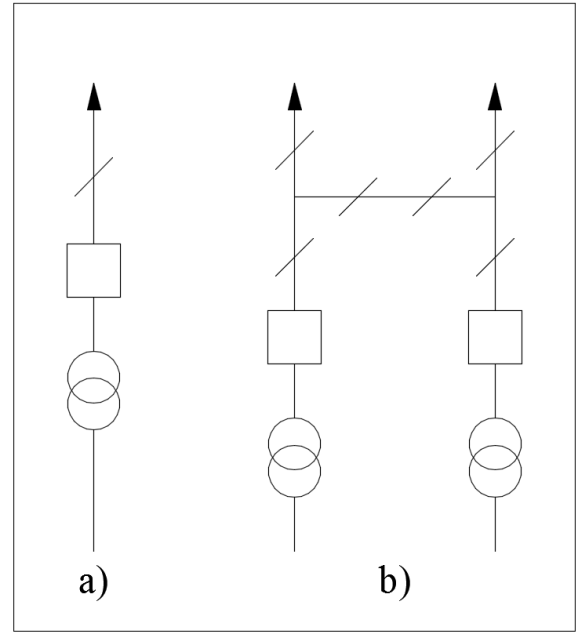

Fig. 3. Connection to TSO grid circuits [9]. 
Wind and solar power plant production is stochastic. The estimated installed power is not reached constantly; it is reached in peaks. Therefore, the solution is to commission more wind turbines and "dump" the excess power. Dumping the excess power limits reduces profit and increases the investment payback time.

Energy storage system (ESS) can be a solution to overcoming wind farm with rated power more than $10 \mathrm{MW}$ siting restrictions. By choosing and setting up a correct ESS, it is possible to "shave" peak production power to the allowed DSO maximum by storing surplus energy in ESS and then feeding into the grid when it is most beneficial, for example, to improve wind farm production forecast, which can reach more than $50 \%$ error of energy generation for day ahead [10] or peak shifting as the ESS is able to act as a load or generator to smooth load profile [11].

\section{ANALYSIS}

The wind power is proportional to the air density $\rho$, the intercepting area $A$ (e.g., area of the wind turbine rotor) and the velocity $V$ to the third power [12].

The power of an air mass that flows at speed V through area A can be calculated as follows:
$P_{W}=\frac{1}{2} \rho \mathrm{A} V^{3} C_{p}($ Watts $)$

where $P_{W}$ is power of the wind, $\rho$ is air density $\left(\mathrm{kg} \mathrm{m}^{-3}\right), V$ is the wind speed $\left(\mathrm{ms}^{-1}\right), \mathrm{A}$ is the area of wind turbine rotor $\left(\mathrm{m}^{2}\right)$ and $C_{p}$ is the power coefficient.

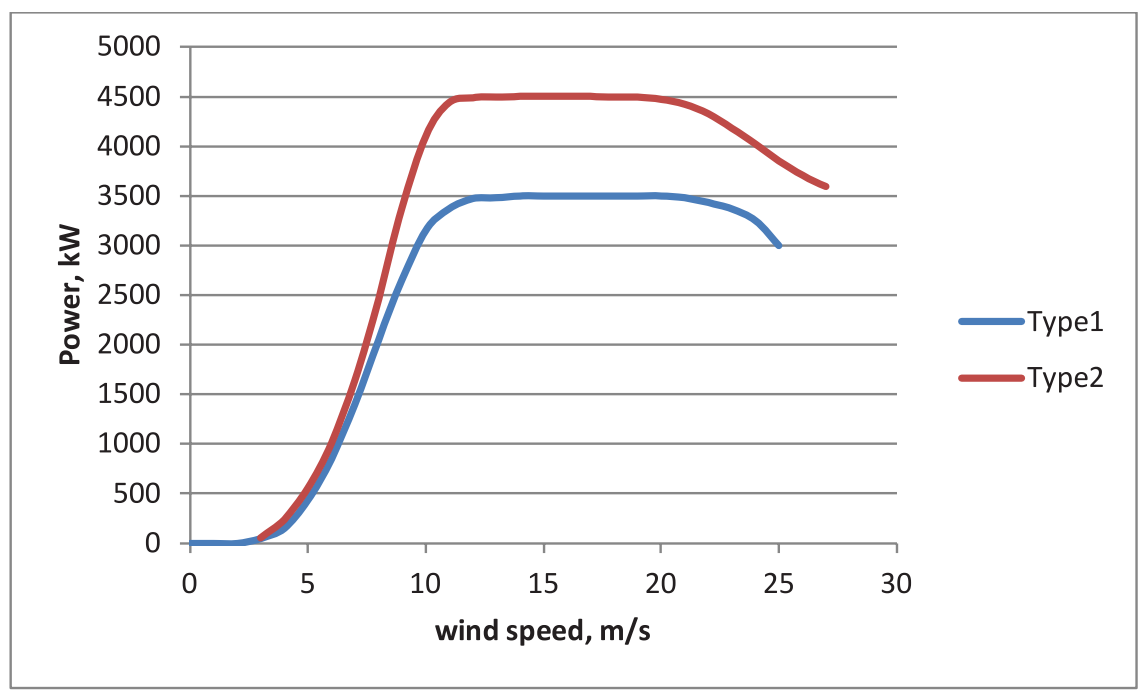

Fig. 4. Two calculated power curves of the wind turbine.

Wind data were obtained from wind farm developers who made wind measurements at the height of $40 \mathrm{~m}, 67 \mathrm{~m}$ and $83 \mathrm{~m}$ in Kurzeme - the western part of Latvia in the coastal area from 2009 to 2011 by using wind measurement masts (a common prac- tice for acquiring accurate wind measurement data) [7], [13]. LIDAR or SODAR wind measurement devices are commonly used nowadays. Wind in this region is the highest in Latvia. These data were used to estimate power production by using two 
yet similar but different turbine calculated power curves for two small scale wind power plants each containing 3 turbines.

For data analysis, the authors of the study chose a wind turbine with the rated power of 3.5 MW, rotor diameter of $138.25 \mathrm{~m}$, hub height of $110 \mathrm{~m}$ (Type 1) and a wind turbine with the rated power of $4.5 \mathrm{MW}$, rotor diameter of $145 \mathrm{~m}$ and hub height of $107.5 \mathrm{~m}$ (Type 2). Two different layouts were examined: firstly, a wind power plant consisting of three turbines of Type 1 with the installed capacity of $10.5 \mathrm{MW}$ and, secondly, a wind power plant consisting of three turbines of Type 2 with the installed capacity of 13.5 MW. Siting ignores layout issues and is designed to minimise the area used (110 to 122 ha). According to Cabinet Regulation No. 240, in Latvia a more strict regulation for siting is applied to five and more wind farms than small-scale wind farms.

The wind speed was calculated according to wind turbine hub heights using Eq. (1). To obtain reliable data, wind measurements were done for more than a year. Energy generation period of 6 months in 2009 is shown in Fig. 5. The figure shows that if the installed power of the wind farm is $13.5 \mathrm{MW}$, the wind farm produces power that exceeds $10 \mathrm{MW}$. The common method to limit the output power of the wind farm is to change a blade pitch angle [14], but the use of such a method will lead to the loss of wind farm production. Installing large-scale ESS can accumulate the excess energy and level out the system power output. In addition, the wind farm can benefit from ESS in terms of the forecast improvement service [15].

Historical data show that the capacity factor of wind farms in the Baltics is around $25 \%$. [16]. The efficiency of wind turbines has grown. In Fig. 6, the power output is sorted to view how much energy per year two different layouts $(3 \times 3.5 \mathrm{MW}$ and $3 \times 4.5 \mathrm{MW}$ ) of wind stations can generate. The first wind power plant generates around $35 \mathrm{GWh}$ per year. The capacity factor of the plant is $38 \%$, which is reasonably high and corresponds to the manufacturer's data. The second wind power plant generates around $44 \mathrm{GWh}$ per year. The capacity factor is $37 \%$. Due to DSO output restrictions (also shown in Fig. 5), 3.5 GWh per year will be dumped if the output power is restricted (Fig. $6(\mathrm{~A})$ ).

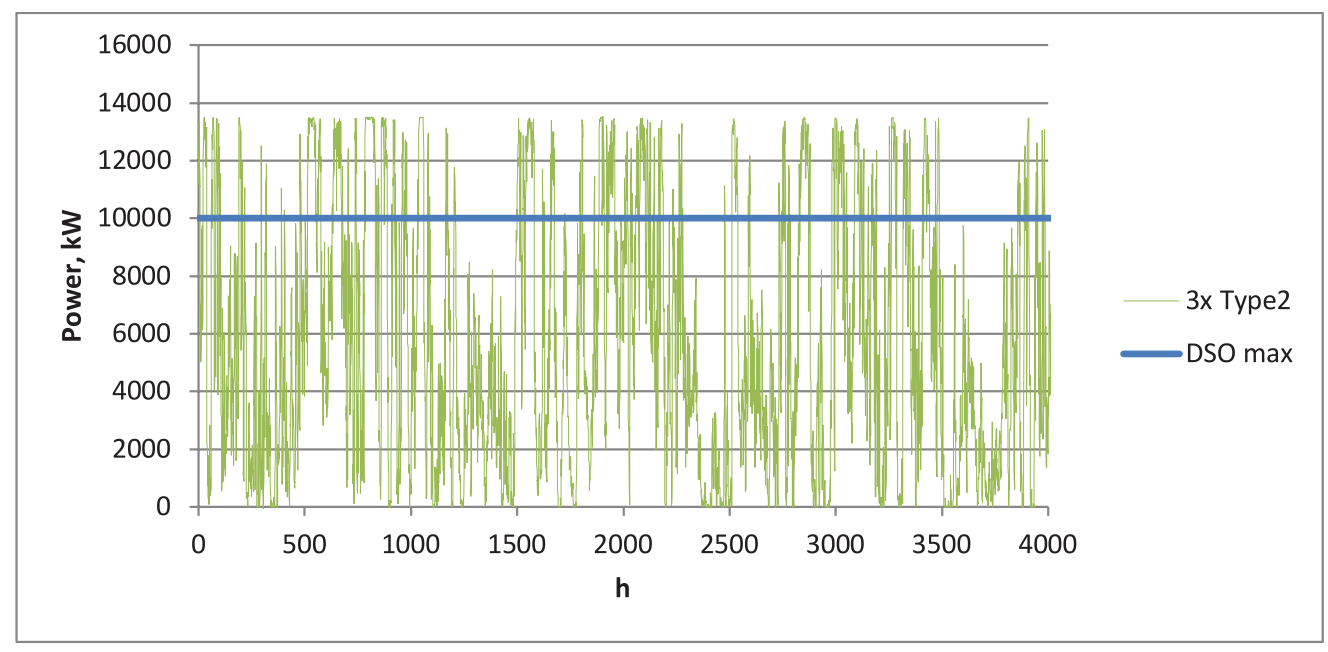

Fig. 5. The estimated production curve of the wind farm (13.5 MW). 


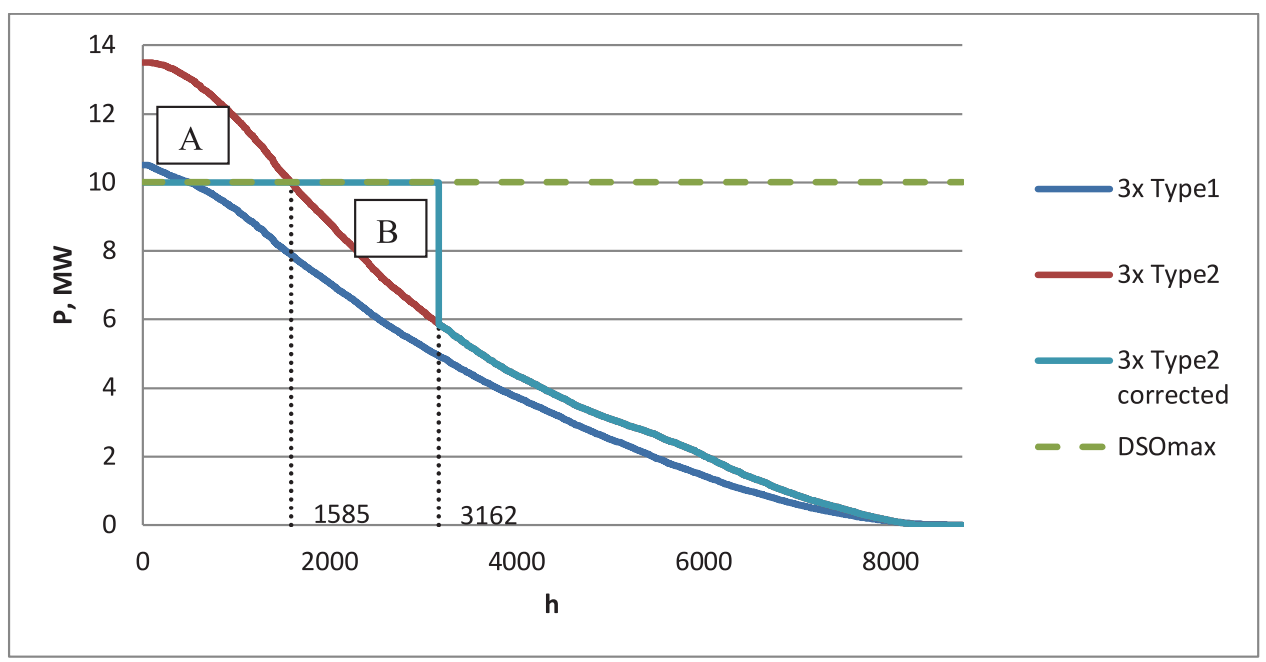

Fig. 6. The sorted production curve of the wind farm (13.5 MW).

\section{CONCLUSIONS}

1. According to statistics and research, ESS can be used as a solution to small wind farm development in Latvia. By overcoming DSO prohibitions of connection, the ESS allows fully exploiting small terrains for wind energy according to the Latvian legislation.

2. Using ESS to store surplus energy and feed it into the grid when the wind is low, it was possible to increase the energy output of wind turbines of the same dimensions by $20 \%$. The feasibility analysis should be performed to validate the long-term viability of the wind power plant.

3. As both small wind farm layouts (ignoring layout issues) with the wind turbine placement occupying the smallest possible terrain are close to 110 ha and 122 ha, it is possible to compare the potential area related gross energy yield. Using ESS and more powerful wind turbines, gross energy yield is $361 \mathrm{MWh} / \mathrm{ha}$ annually, which compared to the other layout (314 MWh/ha ann.) produces $15 \%$ more power.

4. ESS sizing is a complex optimization task with many variables that can strongly affect successfulness of the project. To evaluate how powerful ESS should be to make the project successful and economically feasible, other studies should be performed.

5. This paper has represented an idea of ESS usage for small-scale wind farms in Latvia. The ESS selection, sizing and feasibility analysis should be performed to estimate conditions when this method is viable.

\section{ACKNOWLEDGEMENTS}

The research has been supported by the Department of Electrical Machines and
Apparatus, Riga Technical University. 


\section{REFERENCES}

1. Knapp, L., \& Ladenburg, J. (2015). How Spatial Relationships Influence Economic Preferences for Wind Power. A review, 8, 6177-6201.

2. Zhao, H., Wu, Q., Hu, S., Xu, H., \& Rasmussen, C.N. (2015). Review of Energy Storage System for Wind Power Integration Support. Applied Energy, 137, 545-553.

3. Rosaria, M., Nucci, D., Will, A., \& Krug, M. (2020). Deliverable 3.6. Catalogue of Potential Solutions to Overcome Acceptance Barriers for Each Country.

4. Ministru kabinets. (2013). Ministru kabineta noteikumi Nr. 240. Vispārīgie teritorijas plānošanas, izmantošanas un apbūves noteikumi. Latvijas vēstnesis, 21 (5), 41.

5. Windustry. (2008). Community Wind Toolbox. Minnesota.

6. Bañuelos-Ruedas, F., Ángeles Camacho, C., \& Rios-Marcuello, S. (2011). Methodologies used in the extrapolation of wind speed data at different heights and its impact in the wind energy resource assessment in a region. In Gastón O. Suvire (ed.), Wind Farm - Technical Regulations, Potential Estimation and Siting Assessment. IntechOpen.

7. European Wind Energy Association. (2012). Wind energy - The facts: A guide to the technology, economics and future of wind power. London: Earthscan.

8. IEEE. (2018). Standard for Interconnection and Interoperability of Distributed Energy Resources with Associated Electric Power Systems Interfaces.
9. Knipšis, A. (2012). Elektrisko pārvades tīklu elektroietaišu ekspluatācija. Rīga.

10. Holttinen, H., Miettinen, J. \& Sillanpää, S. (2013). Wind power forecasting accuracy and uncertainty in Finland. Espoo: VTT Technical Research Centre of Finland.

11. Awasthi, A., Karthikeyan, V., Das, V., Rajasekar, S., \& Singh, A. K. (2017). Energy Storage Systems in Solar-Wind Hybrid Renewable Systems. Green Energy and Technology, 189-222.

12. Ackermann, T. (ed.) (2012). Wind power in power systems (2nd ed.). England: John Wiley \& Sons, Ltd.

13. Wizelius, T. (2012). Design and Implementation of a Wind Power Project. Comprehensive Renewable Energy, 391-430.

14. Korchinski, W. (2012). The limits of wind power. Los Angeles: Reason Foundation.

15. Swierczynski, M., Teodorescu, R., Rasmussen, C. N., Rodriguez, P., \& Vikelgaard, H. (2010). Overview of the energy storage systems for wind power integration enhancement. In IEEE International Symposium on Industrial Electronics, 4-7 July 2010, Bari, Italy.

16. Metlovs, S. (2013). Vèja elektrostaciju, kāa arī citu atjaunīgo energoresursu izmantojošo elektrostaciju jaudas regulēšanas iespēju izpēte. Rīga: RTU. 